\title{
Insurance as Strategy for Flood Risk Management at Limpopo River Basin - A decision making Process under Uncertainty
}

\author{
$1^{\text {st }}$ Avelino I. Mondlane, $2^{\text {nd }}$ Karin Hansson and $3^{\text {rd }}$ Oliver B. Popov \\ $1^{\text {st }}$ Department of Computer and Systems Science DSV \\ Stockholm University FORUM 100, Isafjordsgatan 39 \\ Kista 16440 Stockholm, Sweden \\ si-aim@dsv.su.se \\ Computer Center-Eduardo Mondlane University, Main Campus \\ P.O. Box, 257 Maputo Mozambique \\ mondlane@uem.mz \\ $2^{\text {nd }} ; 3^{\text {rd }}$ Department of Computer and Systems Science DSV \\ Stockholm University FORUM 100, Isafjordsgatan 39 \\ Kista 16440 Stockholm, Sweden \\ $2^{\text {nd }}$ karinh@dsv.su.se and $3^{\text {rd }}$ popov@dsv.su.se
}

\begin{abstract}
The Limpopo River Basin, one of the nine international rivers crossing Mozambique, historically has shown to be cyclically flooded, undermining the economic and social development of its four riparian countries. Local and external added efforts are always in place when floods occur. Nowadays there are recommended ex-ante instruments to prevent floods and one of the most applicable instruments worldwide is insurance. Most of the inhabitants, even governments, affected by Limpopo River Basin are poor, therefore our concern regards the viability to apply insurance as a strategy for flood risk management. Moreover our research investigates to what extent the application of insurance, within two identified communities as case study, might create an added value in the process of decision making on flood risk management for Limpopo River Basin.
\end{abstract}

\section{Indexing terms/Keywords}

Insurance, strategy, decision making, uncertainty, floods.

\section{Academic Discipline And Sub-Disciplines}

Decision theory, Insurance and Systems Analysis;

\section{SUBJECT CLASSIFICATION}

Decision Theory and Computer Science

\section{TYPE (METHOD/APPROACH)}

Research, Literature Analysis, fiekd work and Project teamwork and survey

\section{Council for Innovative Research}

Peer Review Research Publishing System

\author{
Journal: INTERNATIONAL JOURNAL OF COMPUTERS \& TECHNOLOGY \\ Vol 10, No. 8 \\ editor@cirworld.com \\ www.cirworld.com, member.cirworld.com
}




\section{INTRODUCTION}

The Limpopo River Basin, fig. 1 below, flows over a total distance of 1,750 Kilometers from Botswana downstream to Mozambique through Gaza Province from Pafuri to Xai-Xai in a distance of $561 \mathrm{Km}$, [1].

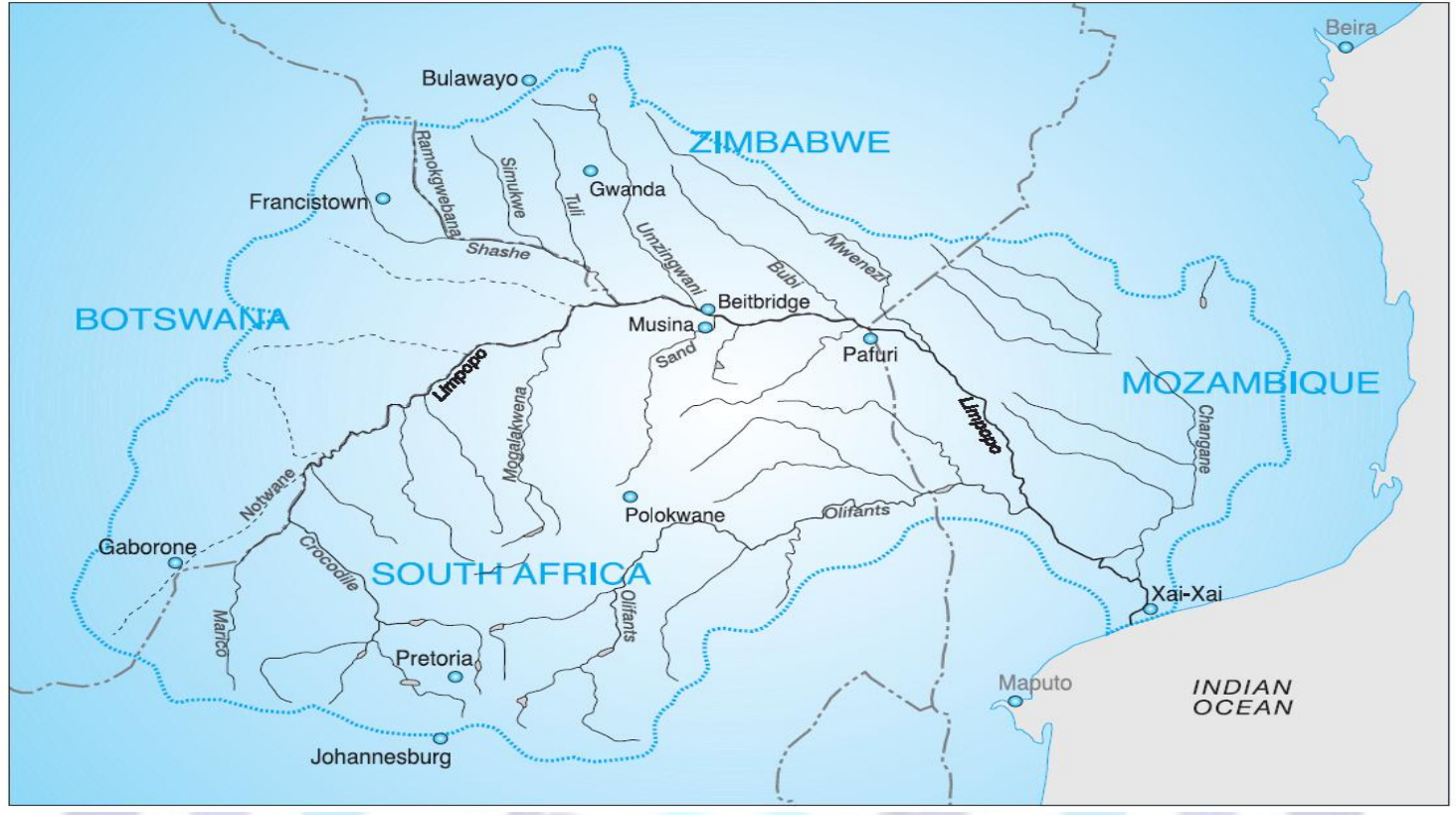

Fig. 1: Proportion of the Limpopo River basin covered by each riparian state Source [2]

The Basin is qualified as the most highly developed basin in the region of Southern African Development Community (SADC), providing economic and social support for about 14 million people living within it [2]. It is characterized by severe floods and droughts. Poverty is reported to be one of the most perennial problems within the basin [3].

Strategically, within Gaza Province, the inhabitants are inventing coping strategies of their own and often rely on kindness of family and friends to cope. Informal traditional, livelihood strategies such as farming, mutual work, work for food, moneylender, seed voucher, community farm, kinship among other are applied in order to enhance livelihood outcomes.

The above strategies are part of usual, cultural and ethical shared principles and values preserved by the communities. Usually they are implemented with harmony, but sometimes are forcefully broken if a disaster occurs, since the surviving needs might increase. Gender issue is of special importance in Gaza where women play the key strategic roles within agriculture, water supply and even in health-home care. Usually the males migrate from the early stage to the main towns and/or South Africa looking for job opportunities.

\section{Purpose and Motivation}

The article presents and evaluates the application of a set of coping strategies based on a particular situation in Gaza Province, where case studies between two communities are compared. The first one is the Samora Machel Millennium Village located in Chibuto District along the Limpopo River Basin, where we carried out the survey, hereinafter called "Chibuto Millennium Village". The second case is an outcome from the Adaptive Project: a collaborative work among Eduardo Mondlane University, the National Institute for Disaster Management "INGC" and Save the Children in "Nwadjahane Community Village" located in Manjacaze district, outside Limpopo basin.

Both communities are frequently affected by natural hazards such as floods and drought and also have similar traditional coping mechanisms. Our analysis lies on the hypothesis that by "providing external financial support and setting up a structured living mechanism communities can shift from their traditional and fragile living mechanisms toward a more secure and long term livelihood outcomes that can strength the resilience to natural hazards".

Therefore, the purpose of this research is to investigate to what extent the application of insurance, within both communities might create an added value in the process of decision making on flood risk management. We aim to evaluate how financial provision can transform existing traditional and local mechanisms in a long term added value for the community livelihood asset empowerment. Based on a simulating tool, the DECIDE-IT Software, using Multi-criteria Decision Analysis (MCDA) for strategic scenarios planning we apply a decision tree models for our research.

Constitute the main motivation for this research the fact that the "Chibuto Millennium Village" has shown positive change and a paradigm ship as learning society when after the implementation of the Project, where people could migrate from their traditional ways of surviving to a more technical supported coping mechanisms. 
The article has six sections, starting with the introduction where we present a shor background of the Limpopo river basin, we introduce the two communities under study and it ends with a purpose and motivation. Second section focuses on poverty as the main reason for developing the insurance policies. It explores the worldwide impact of natural disasters and their coverage by insurance industry, highlighting most of researches developed on insurance for less developed world.

The third section proposes the creation and regulation of viable micro-insurance based on Viable System Model developed by Beer [4] ,[5], [6] and [7], taking into consideration of the ownership of the beneficiaries. Here are summarized the details of the two case and their common coping mechanisms. Section four develops Multi-criteria Decision Analysis processes and scenario planning by analyzing the outputs from the DECIDE-IT Software and their possible implications within both case studies. Section five addresses our findings and recommendations for further research and we end up on section six with analyzing the results and some concluding remarks.

\section{Poverty, Insurance and Global Impact of Natural Disaster}

"We need to be more and more creative and imaginative about the serious consequences. When it comes to the case where society is going to almost collapse in terms of population and communities, everyone has to be there as a participant. It is extremely important to involve scientists from different fields, politicians, regulators, and insurance companies" [8].

From the above statement one can understand that the world is no longer the same where the rich and poor are located in different extremes of a rope when a disaster strikes. More than ever the disaster risk management strategies need to be shared as common concern worldwide. Based on Bali Action Plan roadmap, for risk sharing and transfer mechanisms for the developing countries, particularly vulnerable to climate change insurance is an advisable tool for vulnerable countries like Mozambique. "The action Plan strengthens the mandate to consider insurance instruments as set out by article 4.8 of the UN Framework Convention on Climate change (UNFCCC) and Article 3.14 of the Kyoto Protocol' [9].

In 2011 natural catastrophes and man-made disasters have caused economic losses of about \$SD 370 billion, [10]. On another hand, the 2011 statistics from Munich Re [8] show that $91 \%$ of the world's natural catastrophes were weather related with 300 storms and 310 floods. Bayer [11] argue that insurance is just one tool among many preventing or mitigating options for managing risks of natural hazards and investment in human and economic losses within risk management.

The role of insurance on natural catastrophes and man-made disasters within risk management is extensively discussed in [12], [13], [14],[15], [11] and [9]. Disaster prevention can take many forms such as reducing exposure to risks or creating institutions for better response, while disaster risk management consists of risk reduction and risk coping.

The weaken side of insurance has to do with its traditional concept of business orientation if left entirely for market purpose instead of playing a supportive role for reducing the long term effects of climate change on poverty and development. It might have negative impact by benefiting only to the wealthier clients and not the most vulnerable to climate change, [16]. On another hand, [17] emphasize the problem of using a financial instrument such as insurance for flooding, while this is often considered uninsurable by the insurance segments.

Among other authors [12] and 2008 and [11] have investigated local strategies such as traditional crop insurance and index-based risk insurance. These strategies are important; nevertheless they are susceptible to generate moral hazard, if implemented without the sense of ownership form beneficiaries. The risk behavior plays a major role in the process of insurance decision making and the financial viability of traditional crop insurance. Option has been questioned due administrative cost and the risk adverse in the selection process. All the above causes are direct consequence of world economic development and are subject to changes, therefore the need for a visionary disaster risk prevention and preparedness.

Gree [18] in [19] discusses change; risk and uncertainty as the three basic characteristics interlinked that are subject to management. He characterize risk management as a process in time that leads to choices under uncertainties made to accommodate conflicting objectives subject to change over time. According to Gregory [22] "Decision analysis is an operations research technique for analyzing complex decisions with multiple (and usually conflicting) objectives and uncertainty". We won gratitude to Ronald Howard, one of the founders by 1964s. Utility thery, philosophy of systems analysis and axioms of probabilities constitiute the core of decision analsys [20]. Raifa [21] wrote his first book on decision analysis book baused on probability and a single objective, net present value, argue [22].

About 140 million people in sub-Saharan Africa are normally exposed to natural hazards such as floods and drought due to lack of coping strategies [23] and [24], 2006 in [12]. Limited financial capabilities and networks make it difficult for poor farms to make higher risk, higher-return investments. As result whenever catastrophes occur, vulnerable families embrace ad hoc strategies, which include reducing the food consumption, removal of kids from school to help in productive activities, selling non productive assets or migration of family members. Selling productive assets such as farming tools and livestock and temporary farming employment to those whom can afford any kind of payment is part of additional survival mechanisms.

Limpopo has been affected by both cyclical floods and severe drought in the last decades. This is associated to lack of infrastructure defense mechanisms to the low lands toward downstream resulting in negative consequences. Fresh memories appoint to the 1971, 1977, 2000 floods and January 2013. The 2000 floods killed about 700 people and affected 2 million people [13] along the main branch of the Limpopo River. The total estimated cost of this disaster was reflected in the loss of about $20 \%$ of Mozambique's gross domestic product for that year [25] and [54]. Traditionally, insurance is not in 
fashion in Mozambique and little or no reference was found in regard to insurance for natural catastrophes, given the magnitude of exposure of the country to natural hazards and the financial limitations of those who are vulnerable to such risk.

The benefits in the form of lower expected losses have to be sufficiently large that it is cost-effective for the insurer to incur the transaction costs of varying the premium based on mitigation behavior. The seriousness of the post-disaster capital gap and the emergence of new insurance tools for evaluating and transferring catastrophes risk to global financial markets have motivated many developing governments as well as development institutions, NGOs and other donor organizations, to consider pre-disaster financial instruments as component of disaster risk management [11].

\section{Local Coping Strategies: the case Study}

\section{Viable Micro-Insurance}

Worldwide, the demand for weather-related insurance is growing and expanding market segments include weatherderivatives applicable to utilities, crop production, and other weather sensitive businesses; Micro insurances appear to be one of the recommended alternatives to the traditional business related insurance processes, for the diverse impacts of power outages [26]. The World Economic Forum report , [27] address three main areas to focus on in the visionary management of natural disasters, namely the raise of awareness, enhancement of resilience and encouragement of preparedness and reinforce the role of financial preparedness. This includes micro insurances as alternative preparedness concept of risk transfer in order to protect people's livelihood.

On micro-insurance for natural disaster risk management in developing countries, [11], [28], [12], [15], [16], [13] and [14] have extensively carried out the research. They discuss the advantages and disadvantages of implementation of such strategies in less developed world. Cultural and ethical issues are among recommended key decisive issues to be taken into consideration when one is to embrace insurance strategies for such segment of people;

Among their research are some examples of well known implemented strategies of success worldwide such: crop indexbased insurance in Malawi, the multi-country disaster insurance in the Caribbean, national disaster insurance programmes in Ethiopia and Mexico, the herds' insurance in Mongolia for the extreme weather losses 'dzuds' and the retrofitted house program earthquake insurance in Turkey [11, [15] and [16]]. On our survey we did not find any reference or evidence of such coping mechanism in Mozambique.

Additionally, they reinforce the need of synergic institutional based resource support, for the success of such programs and different stakeholders such as: local governments, NGOs, international insurance companies and re-insurances companies, international financial institutions like World Bank and MFI, research institutions particularly universities, Provention Consortium, IIASA and regional communities, which play a decisive role to support the micro-insurance process. Insurance business still a branch on progress within Mozambique, covering traditionally the automobile segment, therefore there is need to expand and extend it on diversified areas such as natural hazards.

For example, [30], [31] in [12] and [ 29] sustain the integration of disaster risk reduction within risk transfer tools. This represents an opportunity to create a, "Viable Micro-insurance", market in developing countries, which can provide mechanisms for financing safety net and disaster relief programs, where climate change still a major risk. Mechler et al.[28] propose access to affordable and "Viable risk transfer mechanisms", where insurance constitutes the main concern for Provention, Consortium.

Here, especially the issue of culture, ethics and behavior risk insurance are also explored and recommended in the decision making process, bearing in mind the human risk aversion principle if there is willingness to pay more than their expected losses to prevent a large loss at once from a foreseen, [9] and [31.

Viable Micro-insurance can be amplified by the principle of Viable System Model [4], [5], [6], [7], [32] , [33] and [34]. We mean by Viable Micro-Insurance process an insurance system that sustains the minimum functional criteria by which a given organization (enterprise, community, society etc.) can be self sustainable, independent for its own existence. In this paragraph we restrict ourselves to a simply description of the five sub-systems of the VSM. According to Beer each of these stages must exist and be effective in order for a system to be viable:

- System One deals with operations (operational unit). The operational units are each managed by a divisional management unit, each comprising an area of operational activity and the local management structure responsible for directly managing the operational unit (operational management). All operational units and divisional management units on one level of recursion together form System One.

- System Two is concerned with coordination and it conducts a kind of service function for System One and serves to damp oscillation and other disruptions that occur between the operational units on an operational level.

- System Three is concerned with management it supervises all internal operational activities of all operational units from a higher point of view of the total system.

- System Four is concerned with organizational intelligence. It enables the organization to learn and adapt. It searches the environment of the organization for opportunities and threats.

- System Five deals with policy and the values and beliefs espoused through System Five should be shared with all other elements of the organization. The ethos of the whole viable system is formed by System Five; It embodies supreme values, rules and norms for the stabilization of the whole system. 
By establishing such structured micro-insurance system as whole within remote communities we understand that all stakeholders will play their own role in order to ensure the viability of the process. Beer [4], [5], [6] and [7] combined his expertise in cybernetics "the science of communication and control in organisms and machines", and his study of biological systems to create a generic systems framework that could be used to explain and analyze organizational viability "viability can be defined as the capability to maintain an independent existence in the long run" [35].

Nevertheless, the implementation of Viable Micro-Insurance is a complex issue. It involves different stakeholders that might defend diversified and conflicting objectives and options. The Multi-criteria Decision Analysis is one of the most recommended approaches for carrying out a workshop where everyone can contribute and discuss/offer his/her opinion for possible tradeoffs.

Such brainstorming session might result in different strategic decision thinking. This was one of the approaches used for the Millennium Village Project with the key decision makers from the villagers together with the project team, during the inception phase. The aim of such workshops were to gather as much information as possible from the villagers and integrate their options and needs to the project scope and objectives,

\section{The Case Study}

The present case focuses on coping within Chibuto Millennium Village, where a continuous survey was carried out from June 2006 up to December 2009, when the first author of this research was involved in the inception phase of the project for the first six months. Furthermore he spent two following years as a permanent collaborator. The survey was carried through both formal interviews using questionnaires and/or informal conversation based on daily basis. Some key characteristics of the village are: It covers an area of 1057 ha; and 9 ha of Technical Experimental Centre. It has 13,234 people inhabitants with about $70 \%$ women distributed among 3,260 families and 1,967 children below age of 15 attending primary school.

Table 1: Common Activities/Mutual and traditional Practices1

\begin{tabular}{|c|c|}
\hline Activity/Principle Name & Meaning \\
\hline Chaka & Home-grown, acquainted, close, homelike \\
\hline $\begin{array}{l}\text { Mundoni/Mukhossi } \\
\text { wamina }\end{array}$ & Partner, Friend (from different families usually different community) \\
\hline Xitique & Informal monetary exchange in a cyclical period \\
\hline Tsima & Provision of food and or alcohol by a family in return for group farm work \\
\hline Kutlhaisa & $\begin{array}{l}\text { Management (Creation and keeping) of seeds stock for planting in the next } \\
\text { growing season }\end{array}$ \\
\hline Kuxava & Buy "good" from local of existing markets \\
\hline Kunykiwa & Good given as gift under social relationships \\
\hline Kukombela & Acquiring by simple begging \\
\hline Kuthekela & $\begin{array}{l}\text { Acquiring by begging for letter return' circulation of resources between } \\
\text { different ecological zones" }\end{array}$ \\
\hline Kurimela & Provision of labor (one in need) in exchange of goods and or money \\
\hline Kurimelissa & Acquiring of labor (one in need) in exchange of goods and or money \\
\hline Kulomba & Loan-Basis 'especially for goods e.g. seeds in the period of need" \\
\hline Kutxitxana & Exchange with other scarce resources \\
\hline Kuvekelissa & Give animal(s) to be kept and latter return with offspring \\
\hline Kuvekelissiwa & Receive animal(s) to be kept and latter return with offspring \\
\hline Matsoni/tsoni & Labor exchange between persons with tight relationship \\
\hline Xivunga & Extended version of Matsoni in certain regions (e.g. Manjacaze) \\
\hline Tsala & Traditional place inside of houses where seeds can be stored "Granary" \\
\hline Ganho-Ganho & Food for work provided by the State and or NGOs \\
\hline Agiota & Moneylender (informal act) at the high risk of interest \\
\hline
\end{tabular}

Source: Author

\footnotetext{
${ }^{1}$ See, ([33] Osbahr 2007), [34] Casimiro 2011), ([35] Dava et al. 2003), ( [37] Marsh 2002) and ([55]A Glance at Links 2004)
} 
A part from Chibuto Millennium Village and Nwadjahane Village similar practices are in place among communities living along the Limpopo River Basin such as Xai-Xai and Chokwe districts where researches by [36], [37], [38] and [39] highlight usual, cultural, ethnics and ethical practice within Zongoene and Feniceleni just mention a few. The survey with villager is summarized in Table 1. At international level, [28] and [12] are among many authors that explore similar scenarios to those applied within the two communities and in some other points within Mozambique, which FAO partially name them as mutual assistance institutions in Mozambique [40].

The main concern within such habits is that most of the activities bring positive results while no disaster affect the all region, such as happened in 2000. Also, another insecure part of this practice is that it is applied in an informal way, without any kind of official, so it is our concern that such good practices are not sustained by a formal entity that should be able to bring an added value to the process.

Another important principle to follow under the current conditions is: "Not to keep all your eggs in one basket". One of the best and oldest agricultural strategies to deal with uncertainties of weather is to diversify crops in order to prioritize the likelihood of total failure, even though this means that is not possible to aim for maximum yield less than one particular set of conditions. Similar strategies of diversification can be used in other areas of land and resource management. Risk management and microfinance instruments can further contribute to strategies for coping with the effects of climate change [41]. One successfully coping strategy within the Chibuto Millennium Village was to engage the villager within the experimental field and get technical assistance in their family farms in reward.

To sustain our research a comparative analysis of two communities, namely Chibuto Millennium Village and Nwadjahane Community Village, is carried using a decision tree tool as shown on graphics 1, 2 and 3 below. To characterize both communities, illustrative data are given in Boxes 1 and 2.

For Nwadjahane Community Village, box 1 summarizes the survey from the Adaptive Project in Nwadjahane, Manjacaze District, while box 2, illustrates the information of Chibuto Millennium Village research outcomes from our survey. Being at risk, both communities have shown many ways to share and pool risk, and mutual assistance is one of the most commonly applied strategies among those communities.

The Chibuto Millennium Village in Chibuto district, box 2, was set up as part of Government Strategy for Poverty Alleviation toward the achievement of Millennium Development Goals "MDG" as shown in table 2 below, which illustrates the extended MDGs with the respective yearly budget and correspondent weight, based on the sharing budget percentage. We assume these MDGs as the standard community goals for both villages taking into consideration the Government compromise with Millennium Village Strategies for the country.

Table 2: Millennium Development Goals with Basic Weights for the Budget

\begin{tabular}{|c|c|c|}
\hline Objectives & Description & Basic Weight \\
\hline MDG I & $\begin{array}{l}\text { Eliminate hunger and malnutrition in the village by increasing production, access } \\
\text { and utilization of nutritious foods, with a special focus on improving nutritional } \\
\text { status of pregnant women, nursing mothers and infants under two (MDG } 1 / \\
\text { Macro Economy and Poverty, Economy and Development). }\end{array}$ & 0.138 \\
\hline MDG II & $\begin{array}{l}\text { Improve livelihoods of women and men and increase their incomes beyond } \\
\text { extreme poverty levels for both on- and off-farm activities (MDG } 1 \text { / Economy } \\
\text { and Development, Rural Development). }\end{array}$ & 0.113 \\
\hline MDG III & $\begin{array}{l}\text { Assure full attendance to primary schools for both boys and girls and eliminate } \\
\text { gender disparity in schools (MDG } 2 \text { and } 3 \text { / Human Capital, Gender). }\end{array}$ & 0.15 \\
\hline MDG IV & $\begin{array}{l}\text { Improve access to medical services, especially on improving women's health } \\
\text { and drastically reducing child and maternal mortality (MDG } 4 \text { and } 5 \text { / Human } \\
\text { Capital). }\end{array}$ & 0.161 \\
\hline DMG V & $\begin{array}{l}\text { Decrease rate of infection of HIV/AIDS, malaria, tuberculosis and other major } \\
\text { diseases; and increase access to essential medicines such as antiretroviral } \\
\text { medication (MDG } 6 \text { / Human Capital, HIV/AIDS). }\end{array}$ & 0.111 \\
\hline DMG VI & $\begin{array}{l}\text { Integrate the principles of sustainable development into village programs to } \\
\text { reverse the loss of environmental resources and enhance ecosystem services } \\
\text { (MDG } 7 \text { / Environment). }\end{array}$ & 0.077 \\
\hline MDG VII & $\begin{array}{l}\text { Increase access to clean water and sanitation for households, schools and } \\
\text { medical services (MDG } 7 \text { / Human Capital, Environment, Science and } \\
\text { Technology). }\end{array}$ & 0.222 \\
\hline MDG VIII & $\begin{array}{l}\text { Eliminate the digital divide by making available the benefits of communication } \\
\text { technologies, especially access to the internet and mobile telephones services } \\
\text { (MDG } 8 \text { / Governance, Science and Technology). }\end{array}$ & 0.028 \\
\hline
\end{tabular}

Source: Authors, based on Base de Dados da Vila do Milénio (2007). 
Table 2 illustrates the extended version of Millennium Development Goals for the Chibuto Millennium Village with the respective budgets and weights of the costs within the project. This information is applied for the decision tree in graphics 1,2 and 3 below.

Table 3: Floods' Budget Scenarios as outcomes from the Basic Weights

\begin{tabular}{|c|c|c|c|c|}
\hline Objectives & $\begin{array}{l}\text { Losses at } 0 \\
\text { Years Floods }\end{array}$ & $\begin{array}{l}\text { Losses at } 10 \\
\text { Years Floods }\end{array}$ & $\begin{array}{l}\text { Losses at } 50 \\
\text { Years Floods }\end{array}$ & $\begin{array}{l}\text { Losses at } 100 \\
\text { Years Floods }\end{array}$ \\
\hline MDG I & $50,000.00$ & $40,000.00$ & $25,000.00$ & $10,000.00$ \\
\hline MDG II & $40,000.00$ & $32,000.00$ & $20,000.00$ & $8,000.00$ \\
\hline MDG III & $54,000.00$ & $43,200.00$ & $27,000.00$ & $10,800.00$ \\
\hline MDG IV & $58,000.00$ & $46,400.00$ & $29,000.00$ & $11,600.00$ \\
\hline DMG V & $40,000.00$ & $32,000.00$ & $20,000.00$ & $8,000.00$ \\
\hline DMG VI & $28,000.00$ & $22,400.00$ & $14,000.00$ & $5,600.00$ \\
\hline MDG VII & $80,000.00$ & $64,000.00$ & $40,000.00$ & $16,000.00$ \\
\hline MDG VIII & $10,000.00$ & $8,000.00$ & $5,000.00$ & $2,000.00$ \\
\hline Total Weight per Scenario & $360,000.00$ & $288,000.00$ & $180,000.00$ & $72,000.00$ \\
\hline
\end{tabular}

\section{Source: Authors}

By extrapolating monetary data using column two in table 3, we generated three additional scenarios as outcome for possible 10, 50 and 100 floods over the external budget provided to the villagers, in Chibuto, under the ongoing project. Our approach is based on that in case of no floods there might be a basic total budget of USD 360,000.00 per year, while in case of floods of 10,50 and 100 years the budget will be affected by $20 \%, 50 \%$ and $80 \%$ resulting in $288,000.00$, USD $180,000.00$ and USD 72,000.00 respectively. The applications of those monetary values are simulated on decision trees, representing different scenarios illustrated in graphics 1,2 and 5 in section 4. The MDG aim to minimize the level of poverty and maximize the human development index. For this purpose we introduce the Multiple Poverty index as an Overal (MDG Goal) that can influene or being influenced by three main criteria: health, education and standard of living, which through a subjective maping process generate attributes that lead to two main alternatives:intensity of poverty and headcount ratio, see fig.2. These alternatives is well manageg can pool the MPI for MDGs achievements.

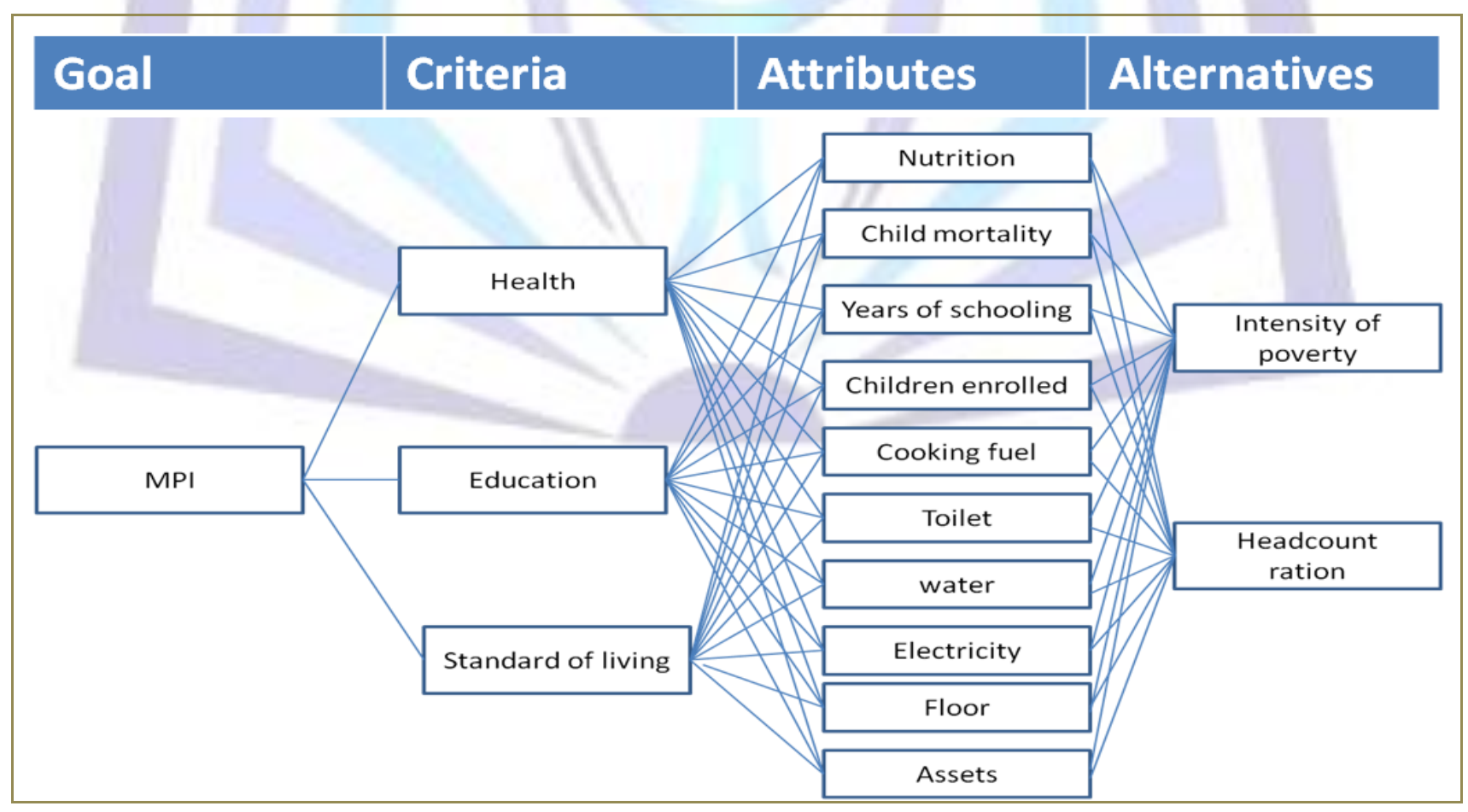

Fig 2. MCDA Value Tree Structure for MPI, Authors

Figure 2 depicts how we can model the Multiple Poverty Index (MPI), based on three criteria to influence the level of poverty and the head count ratio and vice-versa. MPI comprise different set of variables that impact directlty poverty. 
Box 1: Nwadjahane Village2 Characteristics

\begin{tabular}{|c|c|}
\hline Name & Nwadjahane village \\
\hline Location & Manjacaze District- Gaza Province, Mozambique \\
\hline Objectives & Learning to adapt to change ad extreme weather events \\
\hline History & $\begin{array}{l}\text { Nwadjahane is within the district of Manjacaze, and has a special place in history, being the } \\
\text { home of the first post-independence (1975) president of Mozambique (Eduardo Mondlane). } \\
\text { The village has a population of } 601 \text { people, mainly Changana, and there are } 175 \text { households } \\
\text { (area 4). The majority of these people practice subsistence farming focused on livestock } \\
\text { breeding and rain fed agriculture with some irrigated land. No stakeholder identified to } \\
\text { strengthen their Livelihood model and they relay on the local coping strategies. }\end{array}$ \\
\hline Social Data ${ }^{3}$ & $\begin{array}{l}\text { The average household size was } 7.3 \text { people, the ratio of men to women } 0.90 \text {, and the } \\
\text { population density of the village region is approx. } 45 \text { persons per } \mathrm{km}^{2} \text {. Farming association } \\
\text { especially among poor. }\end{array}$ \\
\hline Geographic data & $\begin{array}{l}\text { There are two seasons in the agricultural year: the hot season (nguva ya timpfula) and the cold } \\
\text { season (nguya ya xiwomiso). People farm areas of highland (sandy soils) and lowland (fertile } \\
\text { loams). Staple crops are maize, rice, potatoes, groundnuts and cassava. Vegetable gardening } \\
\text { and the use of fruits and nuts are important. The area around the village is wooded. Although } \\
\text { people are dependent on natural resources, there is a history of migration for work, especially } \\
\text { to Maputo and to South Africa. Nwadjahane is } 18 \mathrm{~km} \text { from Mandlakazi (nearest town) and 90km } \\
\text { from Xai-Xai, the provincial capital. }\end{array}$ \\
\hline $\begin{array}{l}\text { Economic } \\
\text { activities }\end{array}$ & $\begin{array}{l}\text { Mainly agriculture } \\
\text { Business development especially oriented to: Increased specialization of traditional skills } t \\
\text { prevent market saturation and build basis for exchange of services, livestock such as chicken } \\
\text { creation }\end{array}$ \\
\hline $\begin{array}{l}\text { SWOT Analysis } \\
\text { outline }\end{array}$ & $\begin{array}{l}\text { High livelihood diversity: flexibility in the choice of investment priorities into certain activities } \\
\text { Strong agency: strength and respect of traditional authorities and their role in organizing the } \\
\text { community, educated individuals recognizing their ability to disseminate information and } \\
\text { encourage responsibility, inclusive role of community meeting encourages participation and } \\
\text { builds trust, history of population displacement now beneficial as individuals can have spatial } \\
\text { family network to exploit. Larger households enter exchange systems or can seek work without } \\
\text { damaging labor supply (those with more women chose local non-cash exchange while those } \\
\text { with more men chose sale outside village and migration for cash) }\end{array}$ \\
\hline $\begin{array}{l}\text { Manmade and } \\
\text { Natural } \\
\text { Disasters and } \\
\text { other factors } \\
\text { triggered a need } \\
\text { to change and } \\
\text { adapt }\end{array}$ & $\begin{array}{l}\text { - } \\
\text { - } \\
\text { - } \\
\text { - } \\
\text { - } \\
\text { Risk of of floods (Ndhambi) e.g. } 1977 \text { and } 2000 \text { floods } \\
\text { - } \\
\text { - } \quad \text { Low rate of literacy especially in women } \\
\text { Gender issue (women head of families due to husbands migration) and child head of } \\
\text { families due to HIV/Aids orphan. }\end{array}$ \\
\hline
\end{tabular}

\section{Source: (Tyndall Centre for Climate Change Research 2003)}

From the acquired experience, the villagers from Chibuto are able to share their personal efforts in the community field. They receive in exchange technical assistance, fertilizers and qualified seeds from the government.

Traditional local coping strategies are summarized in table 1 below. The first column indicates the name of the strategies (activity or principle) that might be put in practice, whose meaning is explained on column 2 . For example the fourth row indicates "Xitique": This is an informal way of monetary exchange, done in a rotative and periodical way among the group members. 
Box 2: Chibuto Millennium Village Characteristics

\begin{tabular}{|c|c|}
\hline Name & Chibuto Millennium Village \\
\hline Location & Chibuto District - Gaza Province, Mozambique: Bairro Samora Machel (A, B, C \& D), see Figure 2 below. \\
\hline Objectives & $\begin{array}{l}\text { Empowerment of the villager using "Knowledge Management concepts" based on the Millennium MDO } \\
\text { (see Box } 1 \text { above) combining Science and technology with the local Knowledge, namely on Agriculture, } \\
\text { Education, Water and Sanitation, Health and HIV/Aids. }\end{array}$ \\
\hline History & $\begin{array}{l}\text { Founded on } 1977 \text { after the Limpopo River Basin heavy Floods by the Government of Mozambique for } \\
\text { people settled from low lands residents frequently affected by floods and living under risk. The Millennium } \\
\text { Village was setup by the Ministry of Science and Technology as part of National Program to implement the } \\
\text { Millennium Development Goals in ten experimental sites countrywide. It was the first Village within the } \\
\text { Country and the main aim was to reinforce the poverty alleviation through the combination of local } \\
\text { knowledge and scientific methods on socio-economic activities including cattle creation. }\end{array}$ \\
\hline Social Data $^{4}$ & $\begin{array}{l}\text { 13,234 Inhabitants, 3,260 Families, } 4 \text { Primary schools of grade I. The village had more the } 5,000 \text { people } \\
\text { initially referred as the ideal for a standard Village } 5.1,197 \text { school children aged between } 6 \text { and } 17 \text { years } \\
\text { old from which } 555 \text { were girls (2007). For the same period } 2007-2008 \text { have planned to produce about } 29 \text {, } \\
299.65 \text { Thousands tones of food in the experimental research field; the health centre was not operational } \\
\text { and people were drinking water from } 13 \text { main source such as conventional boreholes using manual } \\
\text { pumps (1) and other based on rope pulling traditional methods. }\end{array}$ \\
\hline $\begin{array}{l}\text { Geographic } \\
\text { data }\end{array}$ & Total area of $1057 \mathrm{Ha}$, with $9 \mathrm{Ha}$ of Research Center see map in figure 2 below; \\
\hline $\begin{array}{l}\text { Economic } \\
\text { activities }\end{array}$ & $\begin{array}{l}\text { Mainly agriculture practiced within an area of } 300 \mathrm{Ha} \text { arable, belonging to a former miners association in a } \\
\text { ratio of } 6 \mathrm{Ha} / \text { Family and } 15 \mathrm{Ha} \text { of Experimental field belonging to the Research Center. Also is provided } \\
\text { agricultural empowerment by providing agricultural extensions for fertilize and seed selection. Apart from } \\
\text { agriculture the residents have technical assistance for livestock creation such as cattle, pigs and chickens. }\end{array}$ \\
\hline $\begin{array}{l}\text { SWOT } \\
\text { Analysis } \\
\text { outline }\end{array}$ & $\begin{array}{l}\text { The main Strengths for the village were the linkage between the Ministry of Science and Technology, } \\
\text { representing the Government of Mozambique and the United Nations, represented by the UNDP; also part } \\
\text { of the population was organized within a cooperative agricultural association to explore the existing land. } \\
\text { The Weaken points were based on the lack of leadership and isolated filed work based on the traditional } \\
\text { methods. Low lands at risk fields' location, low income based activities with lack of supportive tools and } \\
\text { facilities in case of disasters. } \\
\text { Identified Opportunities were based on the implementation of the Program with Research Center } \\
\text { oriented to empower local people with especial focus on gender and innovation in all covered fields of } \\
\text { activities. The Threats were located on lack of trust of the beneficiaries, given the weaken philosophy } \\
\text { applied by the program and weak understanding of the self-belonging to the members. People continue to } \\
\text { the practice their activities, agriculture and cattle creation, within the Limpopo Basin flooding plain. Risk of } \\
\text { social instability for those not included to the village key benefits items; environmental problems and risk } \\
\text { of erosion due to the location on the hill }\end{array}$ \\
\hline $\begin{array}{l}\text { Manmade and } \\
\text { Natural } \\
\text { Disasters and } \\
\text { other factors } \\
\text { triggered a } \\
\text { need to } \\
\text { change and } \\
\text { adapt }\end{array}$ & 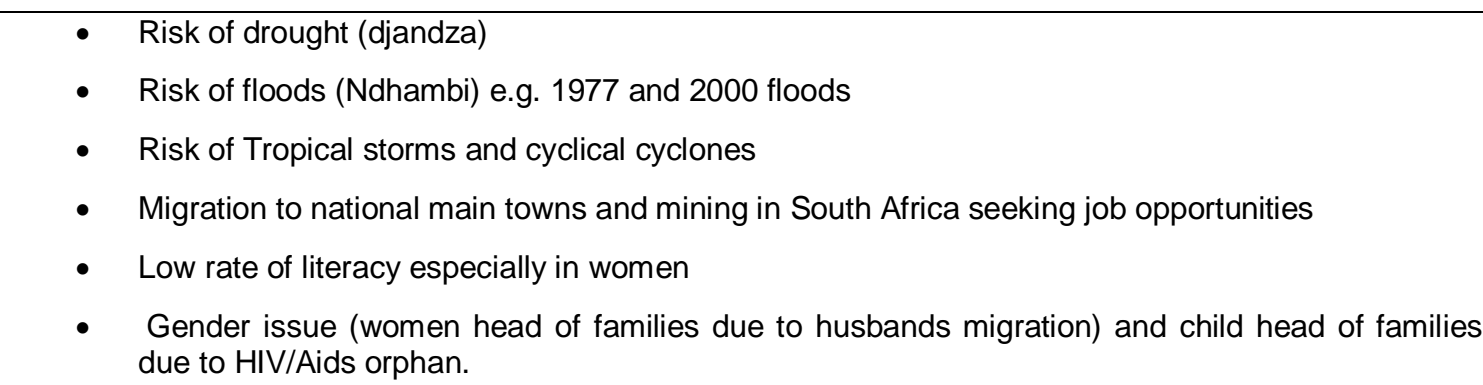 \\
\hline
\end{tabular}

Source: Bilateral Signed Document (2006-2007).

The main difference between the two communities lies on the fact that Chibuto Millennium Village benefited from an external Joint Program between the Government and the UNDP [44] with an estimated yearly budget of about US $\$ 360,000.00$ for a total of 5 years. This stimulated the organizational structure of the villager and also they had an experimental field where they could exchange and acquired practical experience apart from domestic field, which benefit from government technical assistance

\footnotetext{
4 [43] Base de Dados da Vila do Milénio (2007).

5 [44] UNDP-Governo de Moçambique (2006-2007)
} 
Given the uncertainty and the impact of climate change among other factors the best practices of such strategic mutual activities, the livelihood coping outcomes are positive since to some extent they ensure the increase of income, enhance wellbeing, reduce vulnerability, and improve food security and more sustainable use of natural resource based strategies.

\section{Multi-criteria Decision Analysis and Scenario Planning}

In decision analysis, utility techniques include utility function elicitation techniques, decision trees, and influence diagrams [22]. Utility function elicitation techniques are extensively discussed in most literature of this topic, see [45], [46], [47]. Decision trees represent an extensive form of probability trees applied by Raiffa [21] and they are are very flexible-they can be used to solve single and multiple objective decision analysis problems using value or utility, argue [22] ." Influence diagrams, developed by Howard and Matheson, are equivalent to decision trees, but have modeling and communication benefits since the diagram suppresses the details of the branches"[ 46].

Graphic 1 illustrate the comparative output decision trees from both villages in a normal basic situation; i.e. no external input is given and the communities can only survive counting with their own means as described in boxes 1 and 2 . For similar situation the planning process is based on contingency plans, using "what ifs" cases, where all villagers must develop their own surviving strategies in case on a disaster.

\section{Graphic1. Decision tree of MDG for the two Villages without external intervetion}

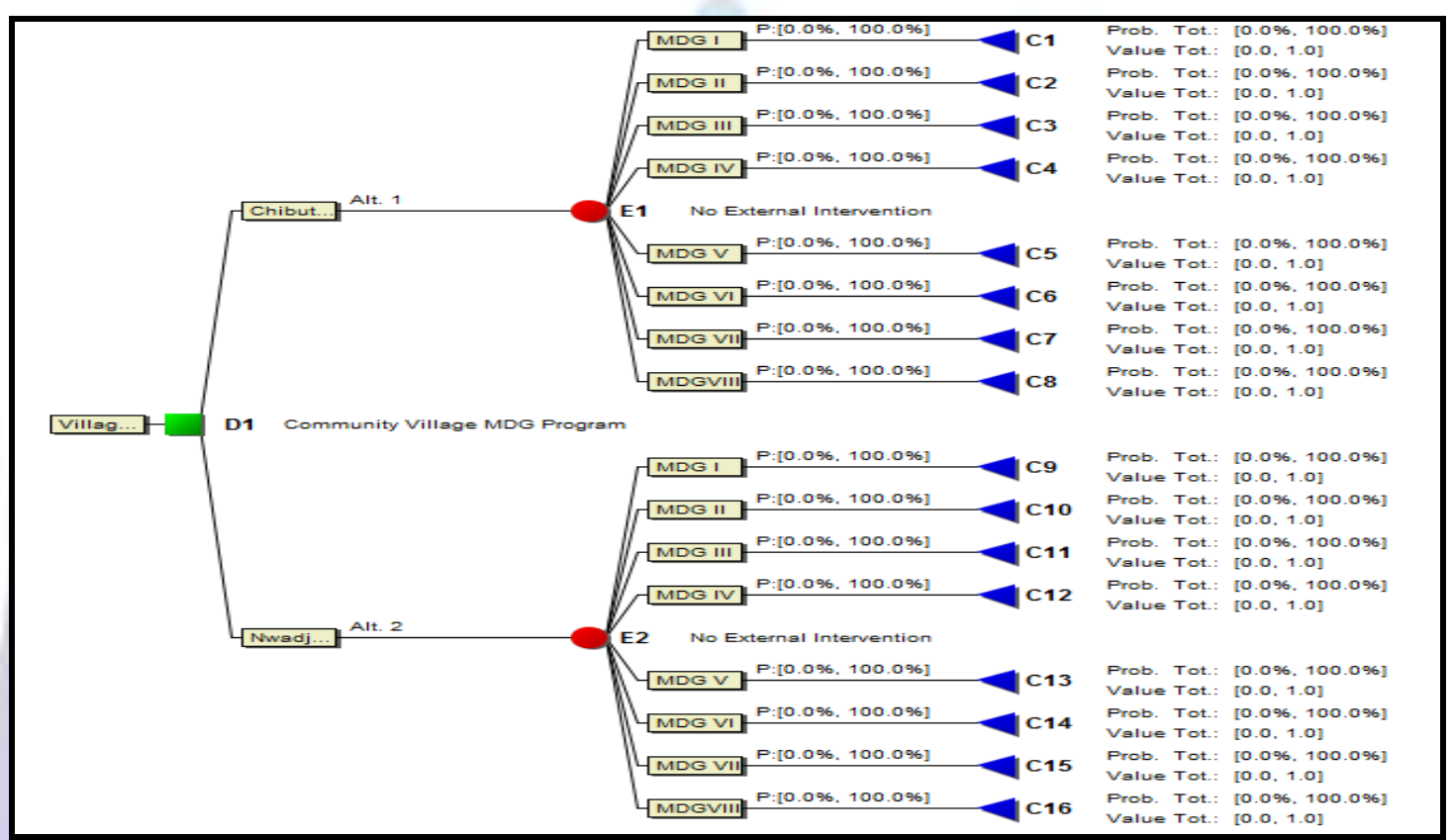

Source: Authors

The Millennium Village Program has on table 9 strategic objectives. To define the priorities and rank them like on table 2 a brainstorming process with the villagers took place. Therefore, given that strategic decisions are carried in a multiple and conflicting objectives direct as to use the Multi-criteria Decision Analysis in our analysis. Analytical Hierarchical Process (AHP) is one of the well known tools of MCDA, developed by Saaty [48] in [49] enables us to develop a comparison of different alternatives, figure 2 , based on the concept of pair wise.

Graphic 2.Comparative analysis for Chibuto and Nwadjahane Villages

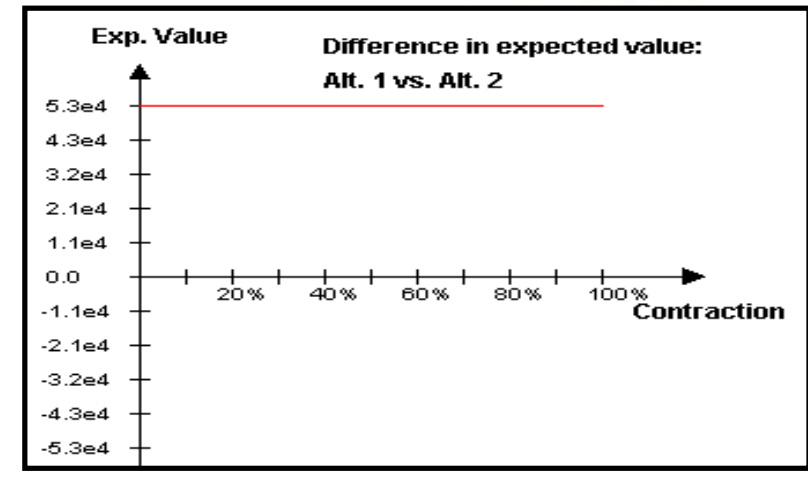

(a)Expected Value with Zero inputs for alt.2

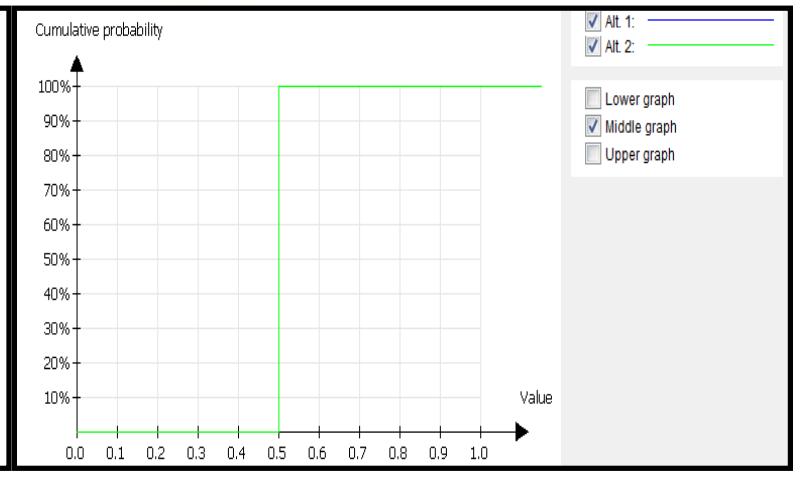

(b) Cumulative Risk Profile (Probabilities) with $100 \%$ Probability of zero inputs for Alt2.

Source: Authors 
Since there is no in prior input with none of the community the outputs in both graphics 2.a and 2.b are the same, i.e. their charts are overlap in red and green line respectively. This is just because there are no priori additional resources within the communities. Notice that both graphics are output from Graphic 1.

Scenario planning is one of the strategic decisions thinking process that can be applied when one is dealing with a multiobjective and conflicting course of actions. Belton and [49] emphasize the application of MCDA and its strength in scenario planning. Graphic 3 is one of the outputs of scenario planning between the two communities if we were given a choice to analyze their performance.

Graphic 3. Decision tree of MDG for the two Villages with external Intervention in Chibuto

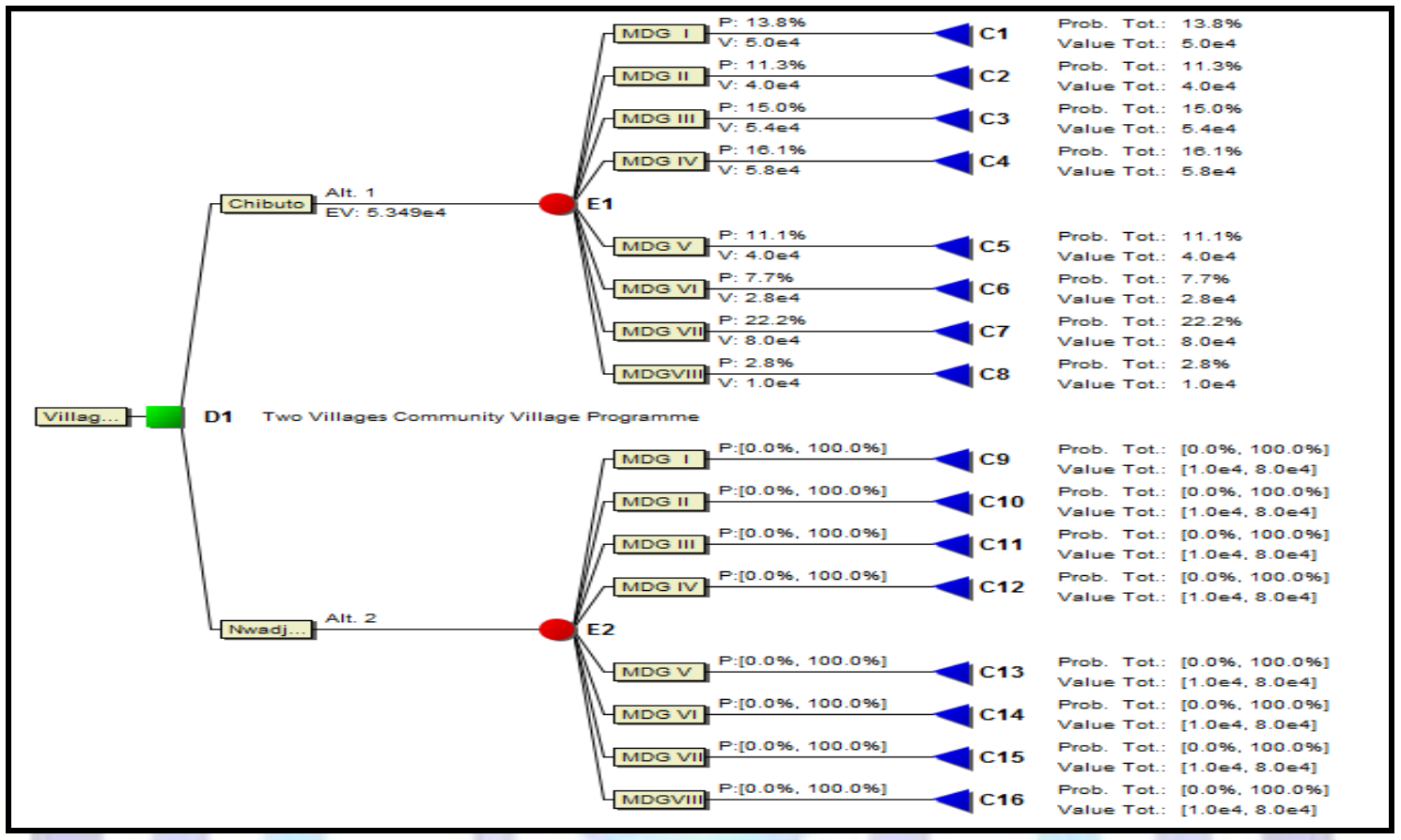

Source: Authors

Alternative 1 "E1" shown on the main branch for Chibuto the figure of Ev: 5.349E4 represents the Expected Value (EV), which means the monetary value that the villagers from this community can have in mind in order to support themselves in making better decisions under conditions of uncertainty. The AHP pair wise comparison can be witnessed on graphic 4 where it is obvious the behavior of both slopes, provided that graphic $4 \mathrm{~b}$, the Chibuto villagers have received some resources in advance, priori to our analysis, hence if a decision has to be made alternative one is preferred to alternative b.

\section{Graphic 4. Pair wise comparison for two scenarios decision analysis}

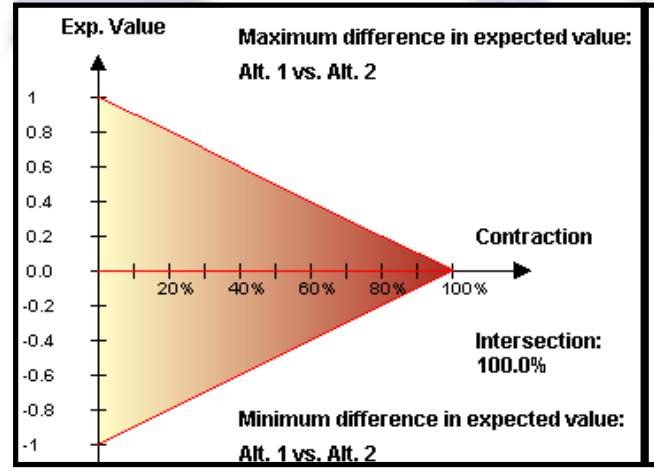

(a) Without financial intervention

(Outcome from graphic 1)

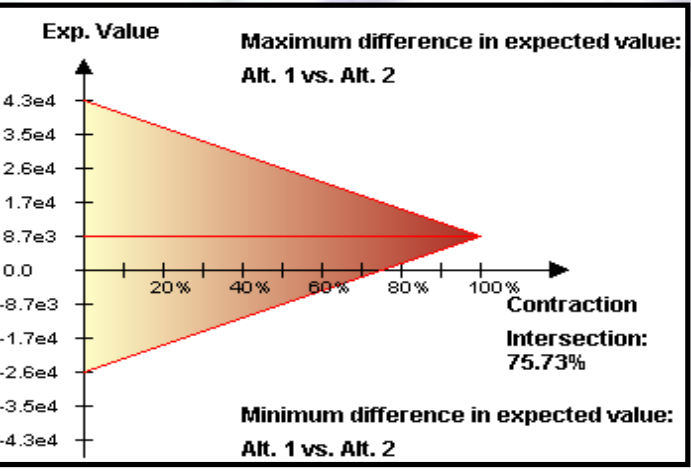

(b) With financial intervention in Chibuto

(Outcome from graphic 2)

\section{Source: Authors}

In this paragraph we will focus our analysis on different scenario planning in Chibuto Millennium Village given the conditions that they have received external resources, but also faced some floods of 10,50 and 100 years with 20,50 and $80 \%$ budget damage respectively. 
Graphic 5. Decision Tree with the 10, 50 and 100 Years Scenarios for Chibuto Millennium Village Livelihood

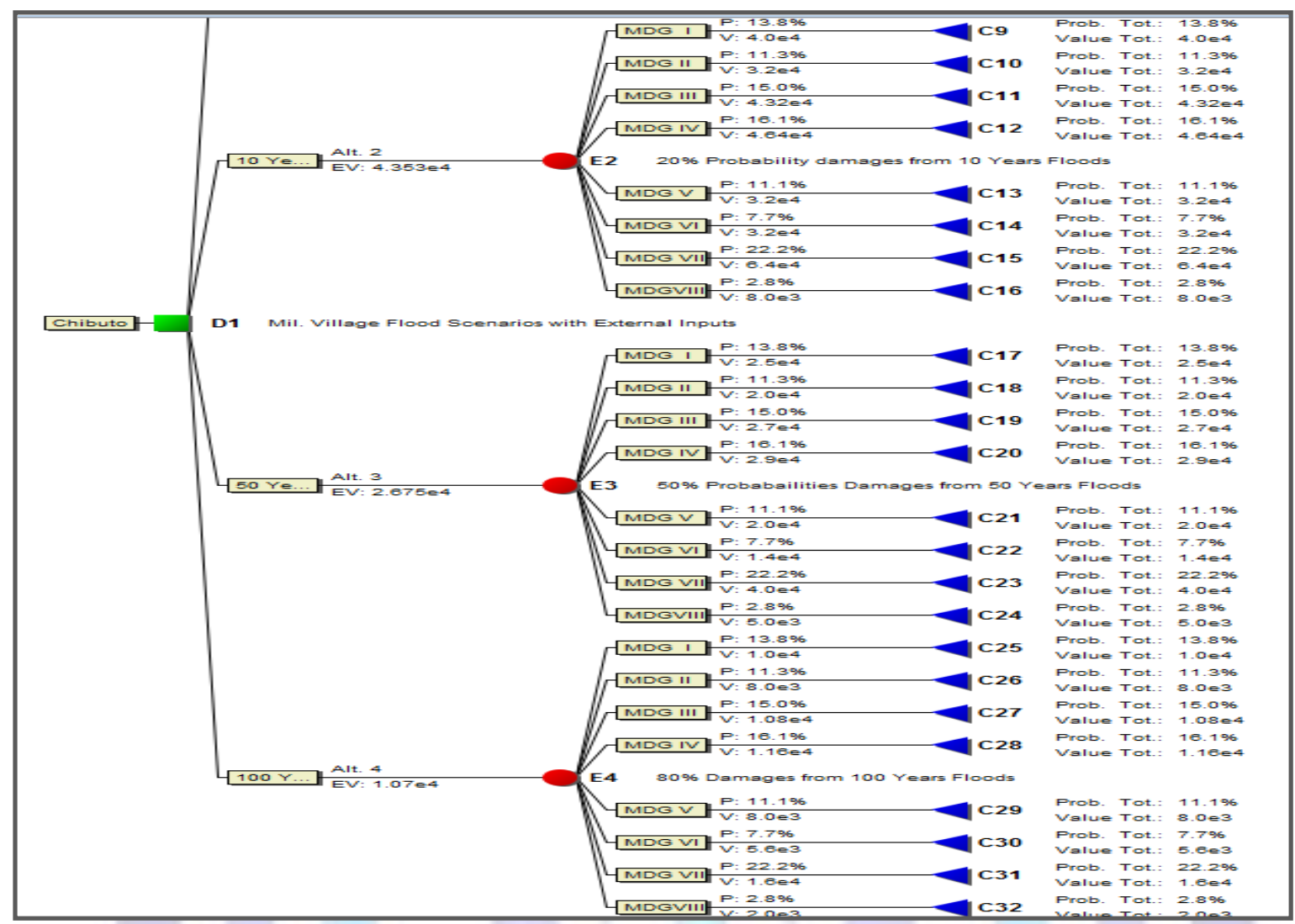

\section{Source: Authors}

Focusing our analysis on the EV rationality we can conclude that in all three scenarios the villagers still have a hope, nevertheless the last one with $80 \%$ of "E4" budget damage, which is the worst case, when compared with previous two. Overall, the first scenario "E2" is the most preferable "the best one"; the second scenario "E3" is preferred to "E4", therefore "E2" is preferred to both "E3" and "E4".

The MCDA for each scenario within Chibuto village, with its own measurement and weights it summarized by graphic 6 , where an overview of extreme values of all four livelihood are compared. Alternative one (no flood scenario) is the most preferable compared to all other three.

\section{Graphic 6.Overview of extreme values of 4 livelihood strategies scenarios}

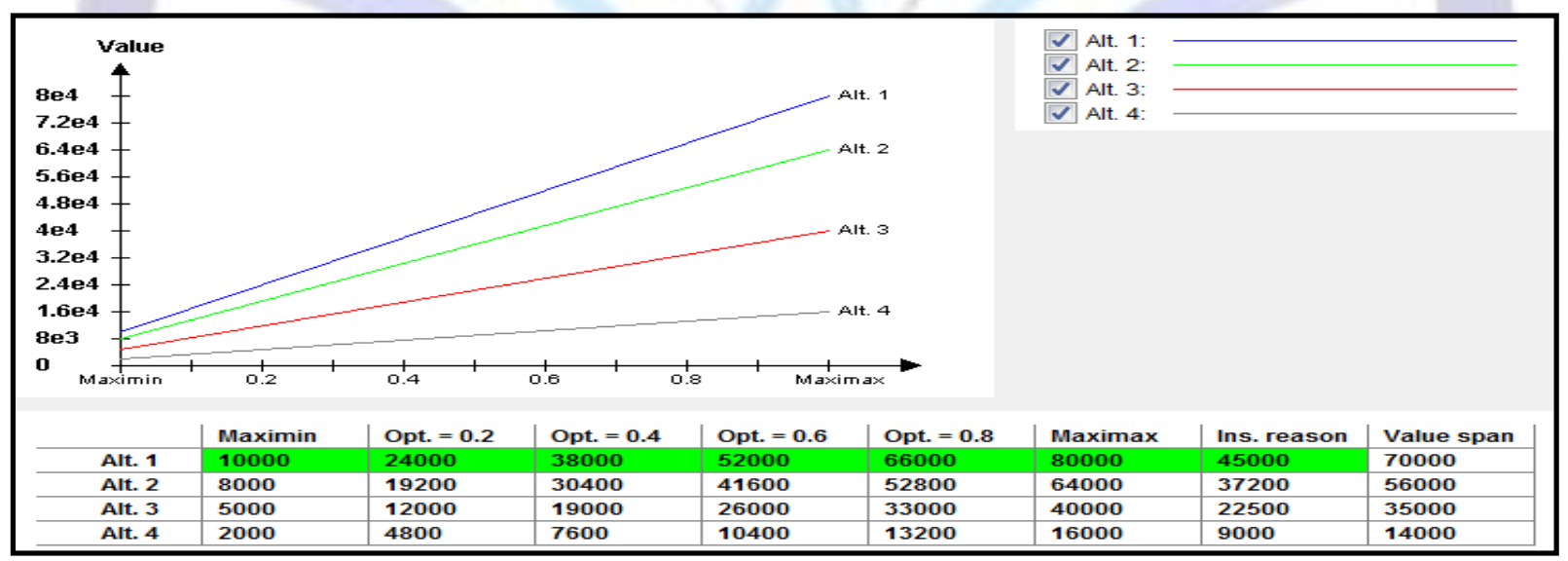

Source: Authors

By integrating more stakeholders such as NGOs, Governmental and private institutions related to disaster risk management, financial organizational insurance and re-insurance companies communities like Chibuto and Nwadjahane can build learning and adaptation mechanisms toward and insurable scenarios. According to Kasperson and Berberian [50] in [51] resilience analysis is a powerful paradigm that embraces systems thinking, focuses on interactions between 
social and ecological subsystems, and assumes change at the core of its analyses. Ideally, the respective strengths of both approaches should be wedded in one integrative framework of analysis.

\section{Findings and Further Research}

From our analyses along this paper we found that most communities living along the Limpopo River Basin have their own coping mechanisms for natural hazards, especially with floods. We also identified that there is shortage of supportive institution from both governmental and private business. The identified strategies for enhancement of their livelihood are limited, but are applicable in cases when natural disasters with small magnitude and do not affect the entire region; it is evident that most instruments applied are based on cultural and local best practices, but are informal lacking any institutional and legal support.

We have found the existence of both formal and informal mutual strategies for coping with emergencies and needs within the communities, see table 1 in section 3.2 above, which are widely applied in Gaza Province and particularly in both studied communities. Also exist among the communities' formal groups that are registered in associations and are somehow tight in existing relationships to a kind of project or microfinance mutual activities. Especial role go to the gender issue where the women play the key leading role in many families as a result of agricultural practice and male earlier migration to the main towns.

For the specific case of Limpopo River basin our understanding is that there is a strong awareness of climate change impact to both governmental entities and local communities. The communities have limited means of living and fragile coping strategies, therefore our recommendation is that based on the existing limited strategies that the Government implements within the Districts the Micro insurance should be taken into consideration.

A Viable Micron insurance approach is recommended for this basin and, here, the government should play the leading role on mobilizing different national and external stakeholder to, gradually design and implement micro insurance mechanisms at the affordable rates. Both cultural and ethical issues should be taken into account when designing such instruments since this has to touch with behavioral and psychological aspects of decision making process.

Existing local governmental entities play a decisive role, but with relative limited alternatives when a disaster strikes, although they still can influence organizational and structural issues. Communities that are isolated such the Nwadjahane in Manjacaze district are left at their own risk, hence will mostly strive to adopt adaptive mechanisms towards a more viable scenario planning for dealing with natural hazards. In Scenario planning for strategic decision thinking, the Multicriteria Decision Analysis plays a key important role to bring all involved stakeholders together in order to identify and chose the suitable scenario and tradeoffs in case of multi objective and conflicting goals.

\section{Results and Concluding Remarks}

When Multicriteria Decision Analysis are used for supporting strategic decisions, its modeling tools must be considered to for dealing with high levels of epistemic uncertainty, confliting objectives and multiple stakeholder situation that might generate long-term consequences [53]. In this paper we used decision amaking to highlight preferences, inferences, classifications, judgments, choices and options whether conscious or unconscious. Such processes studies are not new they last about 300 years and they result from a mix of variety of discplinies and applications in different areas. According to [22] such decisions constitute responses to situations and integrate three main aspects:

- $\quad$ "First, there may be more than one possible course of action under consideration;

- Second, decision makers can form expectations concerning future events that are often described in terms of probabilities or degrees of confidence.

- $\quad$ Three, consequences associated with possible outcomes can be assessed in terms of reflecting personal values and current goals."

By analyzing the outputs illustrated in graphic forms can draw the following short conclusions:

- Graphic 1 highlights the comparative analysis of the two Community Villages where both villagers are taking their ordinary daily activities without any external interventions and the mutual activities listed in table 1, section 3.2, are put in place.

- Graphics 2, 4 and 6 illustrate the pair wise comparison, based on AHP from the scenarios illustted on graphics 1, 3 and 5 respectively. And they highlight the similarity and differences based on correspondents' scenarios analysis.

- $\quad$ Graphic 2 illustrates the scenarios where only the Chibuto community village benefits from external monetary values in a form if project and the applied methodology show that the villagers benefit for each group of goals, see table 3 column 2 in section 5, benefits with a certain budget that totalizes USD 360,000.00 per year.

- Graphic 5 illustrates the three additional flood scenarios namely 10, 50 and 100 years as outputs from the data taken from table 3, columns 3, 4 and 5 in section 3.2, respectively and they complement the zero floods graphic 4, alternative 1 for Chibuto.

- Our analysis from decision trees in graphics 3 and 5 leads to a conclusion that alternative 1 is preferred to alternative 2 and this one is preferred to alternative 3 and finally alternative three to alternative 4 . Therefore we can surely say that the alternative 1 is the best scenario for the community of Chibuto. 
From the previous bullets we can conclude that the Chibuto Community Village is in a better position to implement modern coping mechanisms and if additional financial and structural resources are provided even with a flood of 100 years magnitude still can cope with floods when compared with the one in Nwadjahane that might always start from zero.

Our understanding is that the Government could provide supportive instruments based on the actual financial mechanisms provided to the districts in forms of projects to mitigate risk for the communities with higher exposure. Graphic 7 can probe that even an extreme event if happens in a local where there are mitigating measures the communities might be able to get back on track. In the forthcoming researches we will continue analyzing the impact of micro insurance for the local communities within the Limpopo River Basin.

\section{REFERENCES}

[1] Earle A., Goldin J., Machiridza R., Malzbender D., Manzungu E., Mpho, T. 2006. Indigenous and institutional profile: Limpopo River Basin. Colombo, Sri Lanka: International Water Management Institute. 65p. (IWMI Working Paper 112) ISBN 92-9090-637-5 ISBN 978-92-9090-637-7; 2006, by IWMI.

[2] USAID-RCSA (2002). Limpopo River Basin Fact Sheet 1.Southern Africa Research and Documentation (SARDC). Rua Dom Afonso Henriques, 141, Maputo Mozambique.

[3] SADC: Socio-Economic Situation in SADC, http://www.sadc.int/index/browse/page/108

[4] Beer S. 1981. Brain of the Firm, 2nd ed., reprint, Wiley, Chichester, 1st ed., 1972, Penguin Press, London.

[5] Beer S. 1979. The Heart of Enterprise, John Wiley, London and New York, reprinted 1988, 1994, paperback, ISBN 0 471-94837-3.

[6] Beer S. (1984). The viable system model: its provenance, development, methodology and pathology, The Journal of the Operational Research Society, Vol. 35, No. 1, pp.7-25.

[7] Beers S. 1985. Diagnosing the System for Organization, John Wiley, Chichester and New York, reprinted 1988, 1994, paperback, ISBN 0-471-95136-6. .

[8] Munich Re 2012. TOPICS GEO 2012; Earthquake, flood, nuclear accident; Natural catastrophes 2011 Analyses, assessments, positions.

[9] Bayer J. L., Bals C. and Mechler, R. 2008. Climate Insurance as part of a Post-Kyoto Adaptation Strategy, IIASA, GERMANWATCH.

[10] Suiss Re, 2011. Natural catastrophes and man-made disasters in 2011.

[11] Bayer J. L., Mechler R. and Hochrainer S. 2011. Insurance against Losses from Natural Disasters in Developing Countries. IDRiM (2001) 1(1) DOI10.5595/idrim. Stigler 2011.0013, ISSN: 2185-8322.

[12] Pierro R. and Desai B. 2008. Climate Insurance for the Poor: Challenges for Targeting and Participation. IDS Bulletin Volume 39 Number 4 September 2008. Institute of Development Studies.

[13] Hansson K,, Daielson M., Ekenberg L. and Mondlane A. 2007. Essential Features of a Flood Management Policy Framework. ICT for Environmental Risk Management, Application. IST-Africa 2007 Conference Proceedings, Paul Cunningham and Miriam Cunningham (Eds), IIMC International Information Management Corporation, 2007, ISBN: 1905824-04-1.

[14] Hansson k. 2007. A Framework for Evaluation of Flood Management Strategies. Doctoral Thesis in Computer and Systems Science at Stockholm University, Sweden. DSV Report N007-005. ISSN II0I-8526, ISBN 978091-7155-4383.

[15] Marsh R. 2002. Mutual assistance institutions in Mozambique; Working with local institutions to support sustainable livelihoods; Sustainable Development Department - Food and Agriculture Organization of United Nations, FAO.

[16] Lloyd's, “360॰”.Risk Insight: Micro-insurance Centre. Insurance Developing Countries: Exploring opportunities in Micro-insurance; Lloyd's One Lime Street London EC3M 7HA Telephone +44 (0)20 73271000 Fax +44 (0)20 7626 2389. www.lloyds.com.

[17] Brouwers L. Ekenberg L. Hansson K. and Danielson M., 2004. Multicriteria decision-making strategies with publicprivate re-insurance systems. Risk decision and Policy, 9:23-45, 2004. Taylor \& Francis, ISSN: 1466-4534, DOI: 10.1080/14664530490429535.

[18] Green C., 2003. Change, Risk and uncertainty: managing vulnerability ro floodings. The 3rd IISAS-DPRI Forum.

[19] Amendola A., 2004. Management of Change, Disaster Risk and Uncertainty: An Overview. Journal of Natural Disaster Science, Volume 26, Number 2, 2004, pp 55-61.

[20] Howard R. A. 1988. Decision Analysis: Practice and promise. Management Science 34; 6: 679-695.

[21] Howard R. 1968. Decision Analysis: Introductory lectures on choices under uncertainty. Addison-Wesley (reading, Mass)PUB ID. 101-284-778. 
[22] Gregory S. P., 2009. Decision Analysis in One Chart; Edited by. Dr. Hrishna S. Dhir. Decision Line. Feature Editor, Campbell School of Business, Berry College. www.descisionsciences.org/publicactions.

[23] Bernett, B. J.; Barret. C.B. and Skees, J. R. 2006. Poverty traps and index Based Risk Transfer Products, http://aem.cornell.edu/faculty_sites/cbb2/Papers

[24] Hess U.; Wiseman W., and Robertson T., 2006: Ethiopia Integrated Risk Financing to Protect Livelihoods and Foster Develelopment, Discussion Paper, Adis Ababa: WFP/WB/DFD

[25] UNDP, "United Nations Development Program" 2008. Joint Programme on Environment Mainstreaming and Adaptation to Climate Change Programme/project Duration (Start/end dates): Three years Jan 2008 - Dec 2010 Fund Management.

[26] Mills E. 2007. Synergisms between climate change mitigation and adaptation: an insurance perspective: Mitig. Adapt. Strat. Glob. Change (2007) 12:809-842 DOI 10.1007/s11027-007-9101-x, Springer Science Business Media B.V.

[27] Bruno G. C., Watson T. and Lee, A. 2011. World Economic Forum. A vision for managing natural disaster risk. Proposals for public/private stakeholder solutions; www.weforum.org.

[28] Mechler R., Bayer J. L. with Peppiat D., 2006. Disaster Insurance for the Poor? A Review of Micro-insurance for Natural Disaster risk in developing countries. A Provention/IIASA Study.

[29] Monlane A. I., Hasson K. and Popolo O 2012. Flood Risk Management and the Role o Technology in Decision Making Process. A Multicriteria Decision Support Syeysm. ICUMDM 2012 : International Conference on Uncertainty Modeling and Decision Making-World Academy of Science, Engineering and Technology 72 2012, Penang Malaysia.

[30] Pelling M. and Ultto J. I. 2001. Small Island and develiong states: Natural disaster vulnerability and global change. Environmental Hazards 3 (2001) 49-62

[31] Oliveira A., (2007) A discussion of rational and Psychological Decision-Making Theories and models: The Search for Cultural-ethical Decision Making Model. EJBO Electronic Journal of Business Ethics and organizations Studies Vol.12, No. 2 (2007).

[32] Mondlane, A. I. (2012) 'Behaviour conceptual modelling for vulnerability and risk management using viable system model framework', Int. J. Intercultural Information Management, Vol. 3, No. 1, pp.1-14.

[33] Espejo R. and Harnden R.1989. The Viable System Model. Interpretations and Applications of Stafford Beer's VSM, edited by John Wiley \& Sons Ltd.

[34] Mondlane A. I. HAsson K .and Popov O., 2013. Vulnerability, Human Behaviiour, Hazards and Expected Utility in the Context of Risk Management. An MCDA overview for Limpopo River Basin in Mozambique. Forthcoming from: ICCSNT 2013. Dalian Jiaotong University, DALIAN, CHINA. 3rd Int. Conference on Computer Science and Network Technology

[35] Brocklesby J. and Cummings S., 1996. Designing a Viable Organization Structure, Pergamon: Long Range Planning, Vol. 29, No.1, pp. 49 to 57, 0024-6301(95)00065-8

[36] Osbahr H. 2007. Building resilience: Adaptation mechanisms and mainstreaming for the Poor. Fighting Climate Change: Human Solidarity in a divided world Human Development Report Office 2007/2008.

[37] Casimiro I. M. 20011, Mulheres em actividades Geradoras de rendimentos-Experiencia de Moçambique. Versão XI Congresso Luso-Brasileiro Salvador-Bahia, Agosto de 2011.

[38] Dava F, Muchana J. and Matakala P., 2003. A Gestão da Semente na Segurança. Alimentar: O Caso do Impacto das Cheias de 2000 em Xai-Xai. Links project gender, biodiversity and local knowledge systems for food security Repot N0. $17-2003$

[39] Trædal L. T. 2002. Nor Agric M S c T h e s is. Seeds and Solidarity: A study of seed flow in the year 2000 post-flood situation in southern Mozambique. Centre for International Environment and Development Studies. AGRICULTURAL UNIVERSITY OF NORWAY 2002.

[40] Marsh R. 2003.Working with local Institutions to support sustainable livelihoods, FAO; RURAL Development Division Food and Agriculture Organization of United nations Viale delle Terme di Caracalla, 00100 Rome - ISBN 92-5105048-1.

[41] Haerlin B. and Heine B. Project duration June (2004-December 2006). Adapting to Climate Change, Practical perspectives. Deutsche Gesellschaft für Technische Zusammenarbeit (GTZ) GmbH Climate Protection Programme in Developing Countries Postfach 5180.

[42] Tyndall Centre for Climate Change Research 2003. Adaptive Research Note 8, Research Project at the University of Sheffield, UK.

[43] Ministério da ciência e Tecnologia 2007. Base de dados da Vila do Mlénio de Chibuto: Programa vilas do Milénio. Versão - Final. 
[44] UNDP-Governo de Moçambique (2006-2007). Bilateral Signed Document 'Programa Vilas do Milénio.' e Documento assinado 'Conceito do Programa Vilas do Mielnio'.

[45] Keeney R. L. 1982; Decision Analysis: An overview. Operatioins Research 39 (5); 803-838

[46] Clemen R. T., \& Reilly, T.: Making Hard decisions. (K. Faivre \& E. Davidson, Eds.) (III.). USA. 2001. Duxbury.

[47] Krikwood C. W. 1997. Strategic Decision Multiobjective Decision Analysis with Spreadsheets. Duxubury Press: Belmont, CA.

[48] Saaty T.L. Decision Making for Leaders, 3rd Edition, TRWS Publications, 1995.

[49] Herath G. and Prato T. Using Multi-Criteria Decision Analysis in Natural Resources Management. Ashgate Publishing Company, Bibliografical Index: IBN 0-7546-4596-7, III Series, ISB 978-0-7546-4596-2, 2009.

[50] Belton V. and Stewart T. Multi Criteria Decision Analysis: An Integrated Approach, Kluwer, Dodrecht, 2002.

[51] Kasperson R.E. and Berberian M. 2010. Integrating science and policy: Vulnerability and resilience in global environmental change. London: Earthscan.

[52] Suiss Re, 2010. Risk and resilience: Toward an integrative framework of analysis. Integrative Risk Management: Fostering Infrastructure Resilience Risk Dialogue Series. , Center for Global Dialogue.

[53] Montibeller, G. and Franco L. A.: Raising the bar: strategic multi-criteria decision analysis. Journal of the Operational Research Society (2010), 1-13. Operational Research Society Ltd. All rights reserved. 0160-5682/10. www.palgrave-journals.com/jors/

[54] UNDP 2012. Human Development Report 2011. Sustainability and Equity: A Better Future for All. Explanatory note on 2011 HDR composite indices "Mozambique".

[55] At Glance at Links, 2004. The Role of Social Relations in farmer Seed Systems and Reconstruction of Agricultural Production in a Post-Disaster Situation Links Project Case Study N0. 2 January 2004.

Avelino I. Mondlane is a risk management researcher at Stockholm University Department of Computer and Systems Science. DSV; Forum 100 Isafjordsgatan 39, SE-164 40, Kista, Sweden. He is also with the Eduardo Mondlane University for the last 20 years working in the field of project management and risk analysis at the Centre for Informatics "CIUEM", Julius Nyerere Avenue, P.O. Box 257, Maputo Mozambique (si-aim@dsv.su.se).

Karin Hansson is working within the field of decision analysis, and in particular in the disaster risk reduction area. Modeling and simulating both pre and post coping strategies for disasters in a multi criteria fashion, taking into consideration environmental, social and financial consequences for multiple stakeholders. Karin is a member of the research group DECIDEIT. Department of Computer and Systems Science - DSV; Forum 100 Isafjordsgatan 39, SE164 40, Kista, Sweden (karinh@dsv.su.se).

Oliver B. Popov is a Professor, a Senior Research Scientist at the Department of Computer and Systems Science of Stockholm's University "DSV" where also he is the head of the Systems Analysis and Security Unit. Forum 100 Isafjordsgatan 39, SE-164 40, Kista, Sweden (popov@dsv.su.se). 